УДК 551.51:551.578.4(571.5)

ЭКОЛОГИЧЕСКОЕ СОСТОЯНИЕ ПОБЕРЕЖЬЯ ОЗЕРА БАЙКАЛ И ЕГО ВЛИЯНИЕ НА ЗАГРЯЗНЕНИЕ ОЗЕРА

Белозерцева И.А., Воробьева И.Б., Власова Н.В., Гагаринова О.В., Янчук М.С., Лопатина Д.Н.

Институт географии им. В.Б. Сочавы СО РАН, Иркутск, е-mail: belozia@mail.ru

Зимой - весной 2015-2017 гг. авторы провели отбор проб снега с целью идентификации источников загрязнения снежного покрова, который является индикатором атмосферного загрязнения над акваторией оз. Байкал. Отобрано более 300 проб снега на акватории оз. Байкал и прилегающей территории. Параллельно в зимне-весеннее, летнее и осеннее время были отобраны образцы проб воды оз. Байкал и рек, впадающих в него, а также почв побережья - в летний период (всего > 1000 проб). Результаты химического анализа снега показали аномальные концентрации следующих химических элементов и веществ: $\mathrm{F}, \mathrm{PO}_{4}, \mathrm{Cl}, \mathrm{SO}_{4}$, $\mathrm{NO}_{3}, \mathrm{NO}_{2}, \mathrm{Na}, \mathrm{K}, \mathrm{NH}_{4}, \mathrm{Si}, \mathrm{Fe}, \mathrm{Mo}, \mathrm{Mn}, \mathrm{Ba}, \mathrm{Be}, \mathrm{Al}, \mathrm{Pb}, \mathrm{Cu}, \mathrm{Ni}, \mathrm{V}, \mathrm{Cr}, \mathrm{Zn}$, Ti, Sr, Hg, нефтепродукты, превышающие их фоновые значения. Загрязнение снега и атмосферного воздуха выявлено около населенных пунктов побережья оз. Байкал и в устье реки Селенги. Содержания аммония, свинца, бериллия, ртути и нефтепродуктов в снеге превышают ПДК. В результате проведенных исследований установлено, что современный химический состав воды оз. Байкал, с точки зрения ее питьевых качеств, отвечает требованиям санитарных норм вследствие аккумуляции загрязняющих веществ в почвах и аллювиальных отложениях, а также разбавления огромным количеством воды озера. Исключение составляют некоторые локальные участки прибрежной зоны. В почвах побережья обнаружено локальное повышенное содержание $\mathrm{Mn}, \mathrm{Pb}, \mathrm{Ni}, \mathrm{Co}, \mathrm{Cr}, \mathrm{Zn}$, $\mathrm{Cu}$, превышающее ПДК и ОДК вблизи населенных пунктов. В водах некоторых рек, впадающих в озеро, обнаружены высокие концентрации $\mathrm{F}, \mathrm{Fe}, \mathrm{Pb}, \mathrm{Zn}, \mathrm{Cu}, \mathrm{Ni}, \mathrm{PO}_{4}, \mathrm{NH}_{4}$. Ландшафты устьевых участков рек являются геохимическим барьером для токсических веществ.

Ключевые слова: атмосфера, снег, вода, почва, загрязнение, озеро Байкал

\title{
ECOLOGICAL STATUS OF THE COAST OF LAKE BAIKAL AND ITS INFLUENCE ON THE LAKE POLLUTION
}

\author{
Belozertseva I.A., Vorobeva I.B., Vlasova N.V., Gagarinova O.V., \\ Yanchuk M.S., Lopatina D.N. \\ V.B. Sochava Institute of Geography SB RAS, Irkutsk, e-mail: belozia@mail.ru
}

\begin{abstract}
In the winter and spring periods of 2015-2017, the authors of the current scientific paper collected the snow samples in order to identify the snow cover pollution level which is generally seen as an indicator of the atmosphere pollution in the Baikal water area. More than 300 snow samples have been collected in the water area of Lake Baikal and the adjoining territories. Water samples of Lake Baikal and the rivers flowing into the lake as well as soil samples of its shoreline were also collected at the same period, and in the summer and autumn (total over 1000 samples). The chemical analyses of the snow cover have revealed the anomalies for the following chemical elements and substances: $\mathrm{F}, \mathrm{PO}_{4}, \mathrm{Cl}, \mathrm{SO}_{4}, \mathrm{NO}_{2}, \mathrm{NO}_{3}, \mathrm{~K}, \mathrm{Na}, \mathrm{NH}_{4}, \mathrm{Mo}, \mathrm{Mn}, \mathrm{Ba}, \mathrm{Al}, \mathrm{Pb}, \mathrm{Ni}, \mathrm{Cu}, \mathrm{Be}, \mathrm{V}, \mathrm{Cr}, \mathrm{Fe}, \mathrm{Si}, \mathrm{Zn}, \mathrm{Sr}, \mathrm{Ti}, \mathrm{Hg}$ and petroleum products which all exceed their background concentrations. Air and snow pollution of the lake's water area has been detected near the littoral residential zones and in the estuary of the Selenga River. The concentrations of $\mathrm{NH}_{4}, \mathrm{~Pb}, \mathrm{Be}, \mathrm{Hg}$ and petroleum products in the snow water exceed the MAC. According to the research, the current chemical composition of Lake Baikal's water, in terms of its drinking properties, conforms to health and safety standards due to the accumulation of pollutants in soil and alluvial deposits and their delution with a huge amount of lake water. The only exceptions are some local areas of the shoreline. A local increase in the content of $\mathrm{Mn}, \mathrm{Pb}$, $\mathrm{Ni}, \mathrm{Co}, \mathrm{Cr}, \mathrm{Zn}, \mathrm{Cu}$ which all exceed the MAC and the APC values has been detected near the populated areas. High concentrations of $\mathrm{F}, \mathrm{Fe}, \mathrm{Pb}, \mathrm{Zn}, \mathrm{Cu}, \mathrm{Ni}, \mathrm{PO}_{4}, \mathrm{NH}_{4}$ have been detected in the large rivers flowing into the lake. The landscapes of the rivers' estuaries serve as a geochemical barrier for toxic substances.
\end{abstract}

Keywords: atmosphere, snow, water, soil, pollution, Lake Baikal

Объекты исследования - снег Центральной экологической зоны Байкальской природной территории (ЦЭЗ БПТ), вода акватории оз. Байкал, а также рек, впадающих в озеро, и почв побережья. Объекты являются уникальными, что определено существованием на этой территории самого чистого и глубокого озеpa, объекта всемирного наследия. Это самое большое и пресное озеро на планете. Огромные резервы пресной воды в озере, которые составляют $20 \%$ от общей сум- мы их запасов в мире, а также проблемы нехватки водных ресурсов на земле требуют мирового внимания исследователей. Качество пресной воды оз. Байкал, насыщенной кислородом, с низким содержанием минеральных солей и органических веществ, имеет особую ценность. К сожалению, в Байкальском регионе находятся мощные источники загрязнения окружающей среды. Какую опасность они могут представлять для озера Байкал и его окружающей среды? 


\section{Материалы и методы исследования}

В феврале - марте 2015-2017 гг. авторами проведен отбор проб снега для идентификации загрязнения снежного покрова, который является индикатором атмосферного загрязнения в ЦЭЗ БПТ. Пробоотбор осуществлялся на ключевых площадках с учетом источников поступления загрязняющих веществ и преобладающих ветров (рис. 1). Отобрано более 300 проб снега на акватории оз. Байкал, побережья и прилегающей территории. Параллельно в зимне-весеннее (февраль - март), летнее (июль - август) и осеннее (сентябрь) время были отобраны образцы проб воды оз. Байкал и рек, впадающих в него, а также почв побережья в летний период (всего > 1000 проб). Анализы выполнены в химической лаборатории Института географии им. В.Б. Сочавы СО РАН по стандартным методам (ГОСТам) на современном оборудовании. Химическая лаборатория аккредитована и имеет лицензию на проведение анализов. Содержание основных ионов в воде снега определено стандартизированными химическими мето- дами, учитывающими требования ГОСТов. Концентрации макро- и микроэлементов установлены атомно-эмиссионным спектральным методом (Optima 2000 DV). Coдержание фтора измерялось на иономере, нефтепродуктов - на флюорате.

\section{Результаты исследования и их обсуждение}

В результате проведенных исследований авторов [1-3], а также изданных работ сотрудников различных научно-исследовательских организаций [4-6] возможно сделать вывод, что основные источники атмосферного загрязнения на оз. Байкал - это расположенные в бассейне и на побережье озера промышленные предприятия, Транссибирская и Байкало-Амурская железнодорожные магистрали, воздушный перенос загрязнителей из Иркутско-Черемховского промышленного узла. Воздушные выбросы предприятий и котельных городов Байкальска, Слюдянки, Северобайкальска и поселков, расположенных в котловине Байкала, имеют самую высокую вероятность (10$100 \%)$ попадания в озеро.

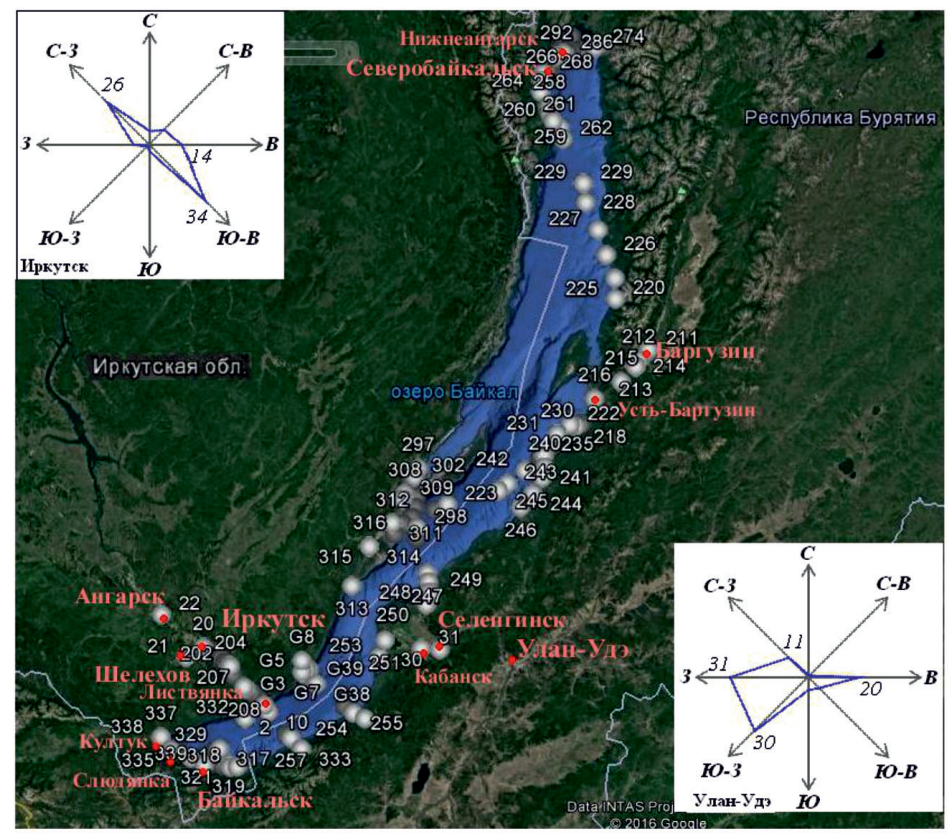

Вклад промышленных отраслей в валовые выбросы, \%
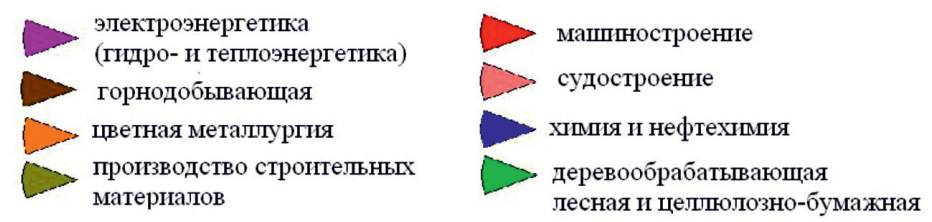
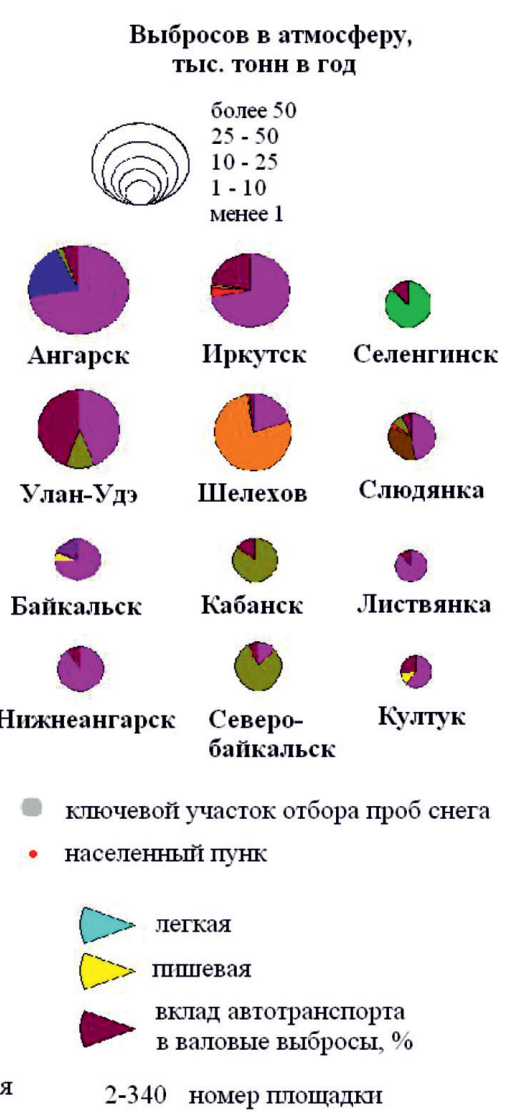

Рис. 1. Точки отбора проб снега и основные источники загрязнения 


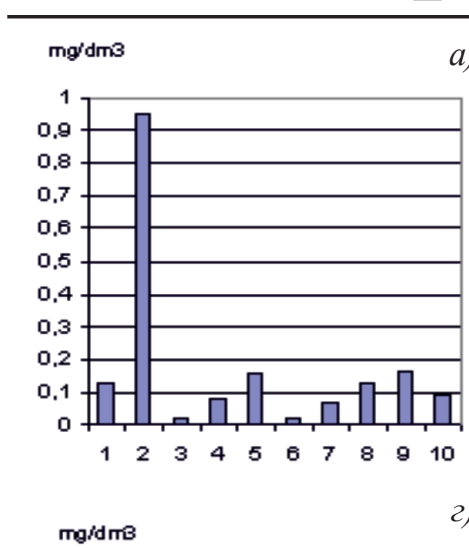

a)

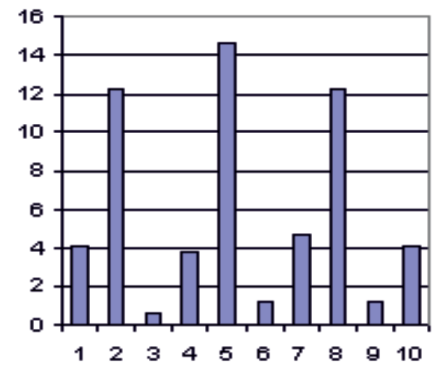

2) $\mathrm{mg} / \mathrm{dm} 3$

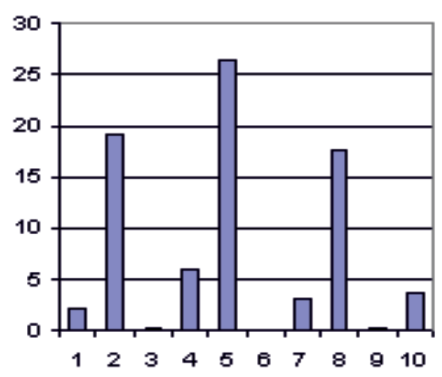

ж)

$\mathrm{mg} / \mathrm{dm} 3$

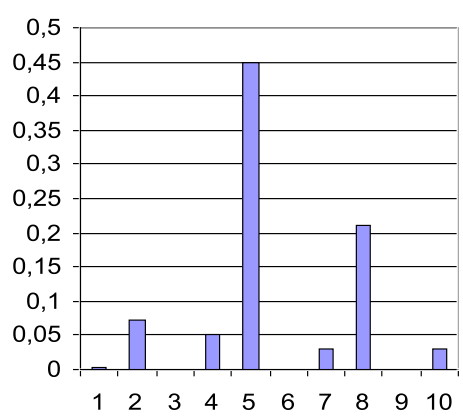

$\mathrm{mg} / \mathrm{dm} 3$

$\kappa)$
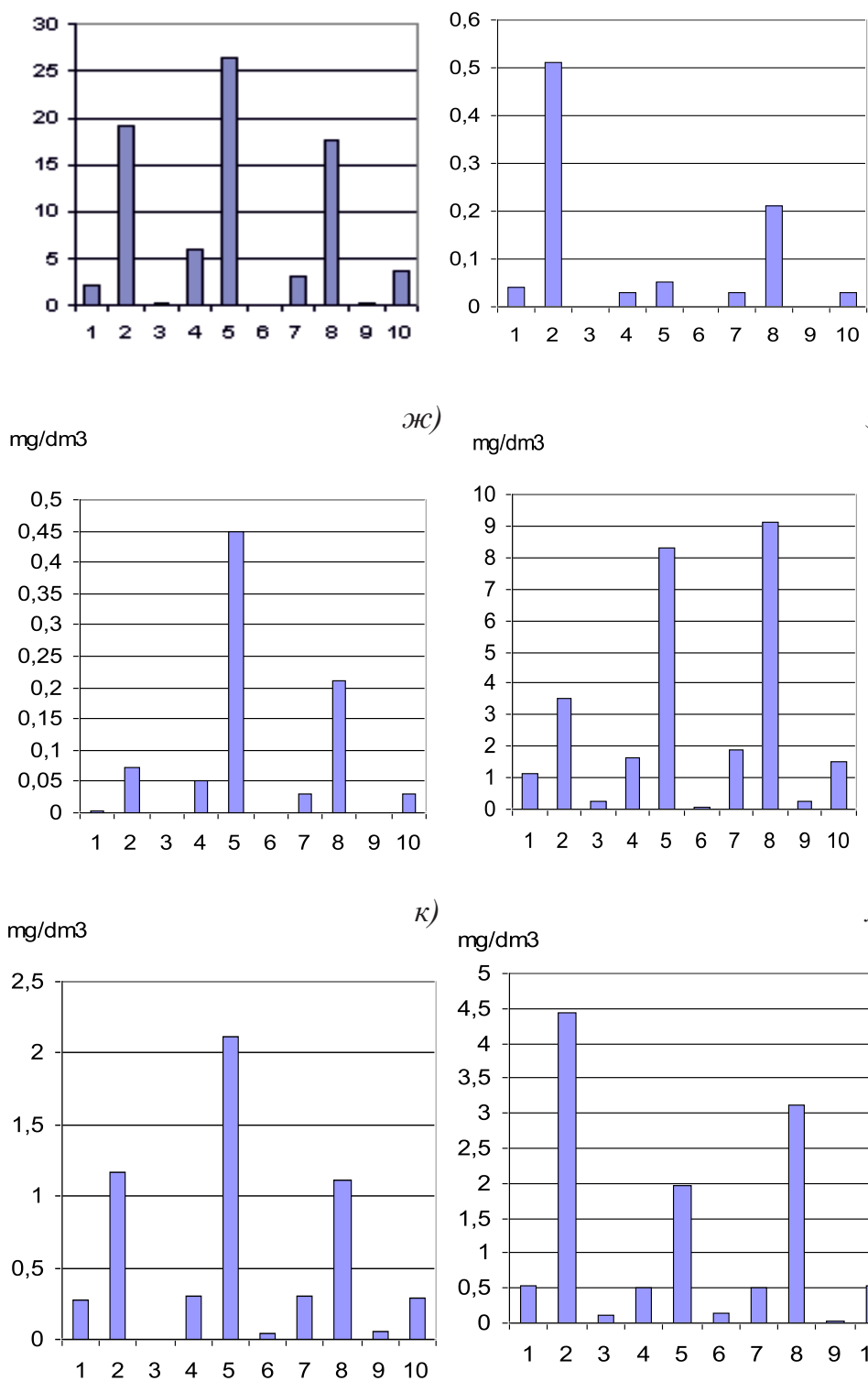

б)

$m g / d m$

в)

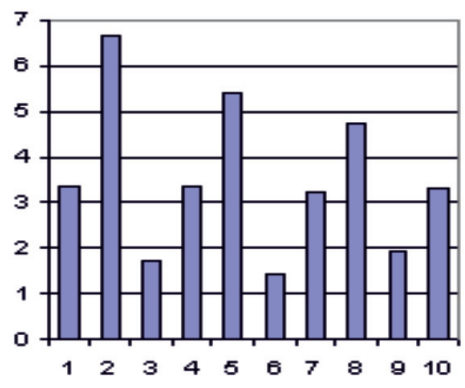

d)

$\mathrm{mg} / \mathrm{dm} 3$

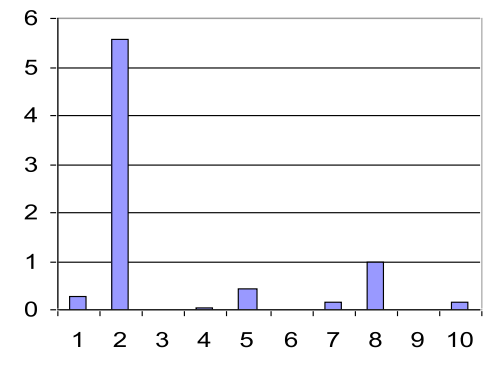

3) $\mathrm{mg} / \mathrm{dm} 3$

u)

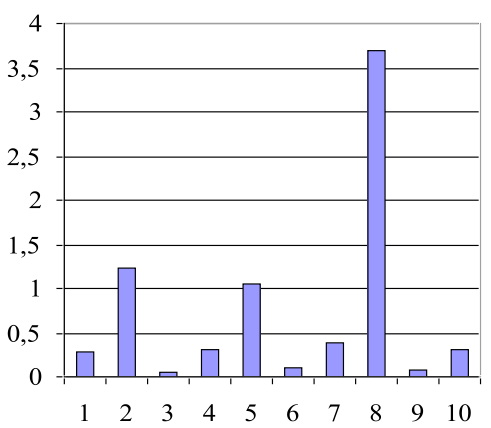

л)

M)
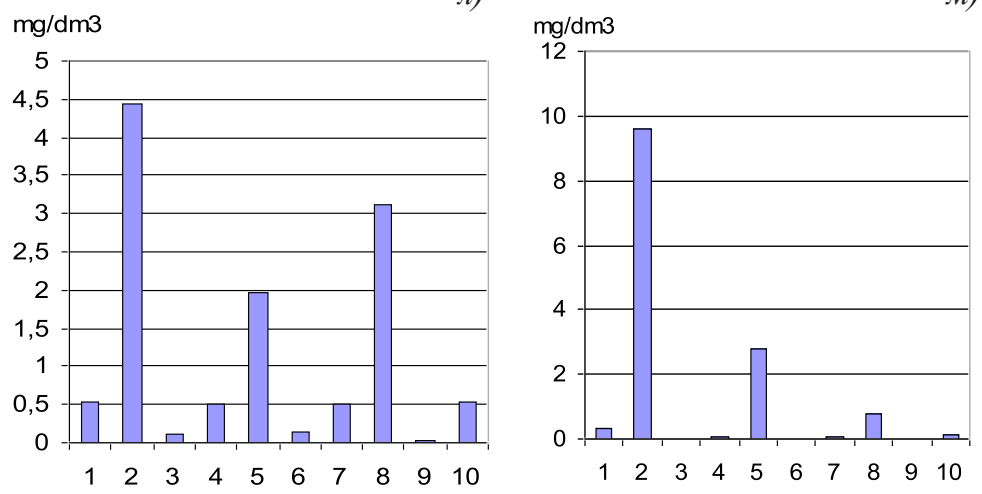

Pис. 2. Содержание химических элементов и веществ а) $\mathrm{F}$, б) $\mathrm{HCO}_{3}$, в) $\mathrm{Cl}$, г) $\mathrm{SO}_{4}$, d) $\mathrm{NO}_{2}$, e) $\mathrm{NO}_{3}$, ж) $\mathrm{PO}_{4}$, з) $\mathrm{Ca}$, и) $\left.\mathrm{Mg}, \kappa\right) \mathrm{K}$, л) $\mathrm{Na}$, м) $\mathrm{NH}_{4}$ в снеговой воде оз. Байкал и прилегающей территории.

Южная котловина: 1 -среднее, 2 -макс., 3 -минимальное содержание; Средняя котловина:

4 -среднее, 5-макс., 6-минимальное содержание; Северная котловина: 7 -среднее,

8 -макс., 9 -минимальное содержание; озеро Байкал всего: 10 - среднее содержание ПДК, ОДК: $\mathrm{F}-0,7-1,5 ; \mathrm{Cl}-350 ; \mathrm{SO}_{4}-500 ; \mathrm{NO}_{3}-130 ; \mathrm{PO}_{4}-0,001 ; \mathrm{Ca}-180$; $\mathrm{Mg}-50 ; \mathrm{K}-40-50 ; \mathrm{Na}-120-200 ; \mathrm{NH}_{4}-0,4 \mathrm{mg} / \mathrm{dm}^{3}$ 


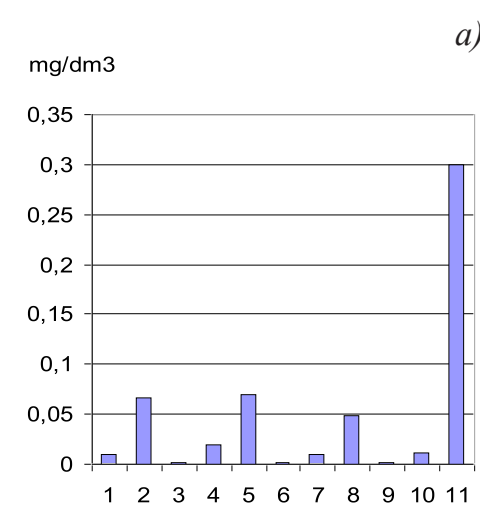

a)

$\mathrm{mg} / \mathrm{dm} 3$

б)

$\mathrm{mg} / \mathrm{dm} 3$

6)
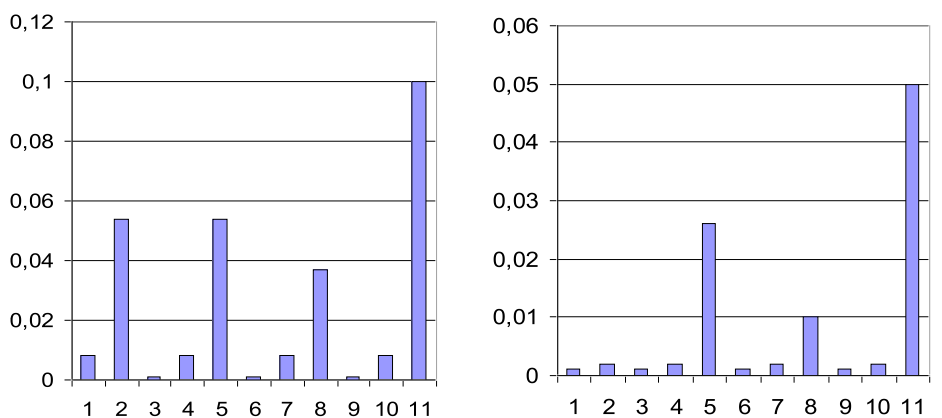

2)

$\mathrm{mg} / \mathrm{dm} 3$

$\mathrm{mg} / \mathrm{dm} 3$

d)
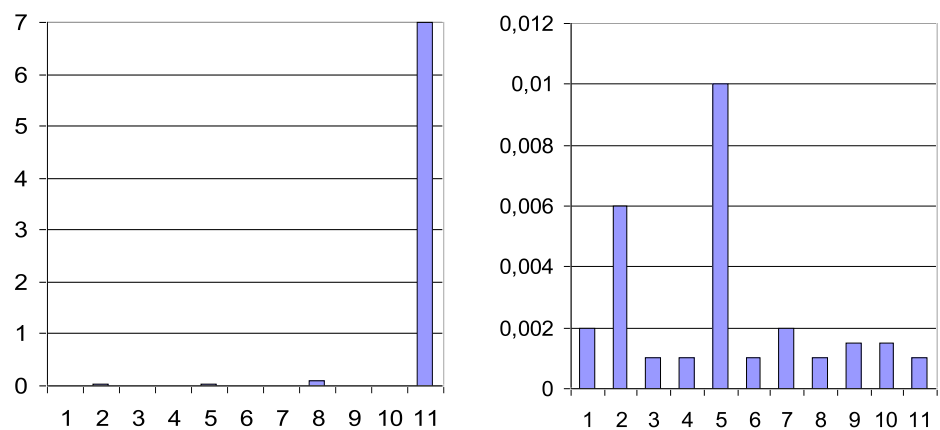

$\mathrm{mg} / \mathrm{dm} 3$

e)

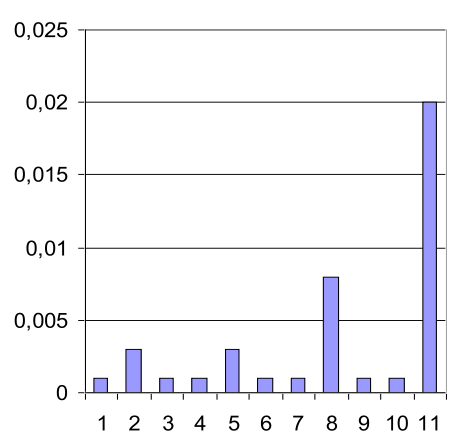

ж)

$\mathrm{mg} / \mathrm{dm} 3$

3)

$\mathrm{mg} / \mathrm{dm} 3$

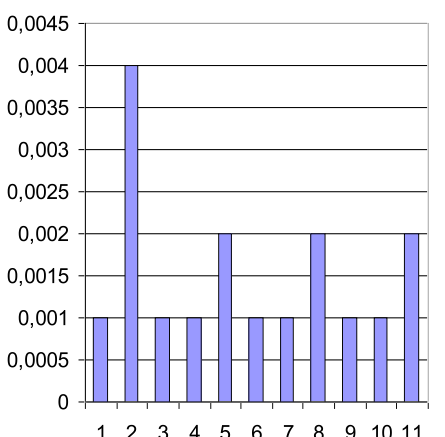

$\mathrm{mcg} / \mathrm{dm} 3$

u)
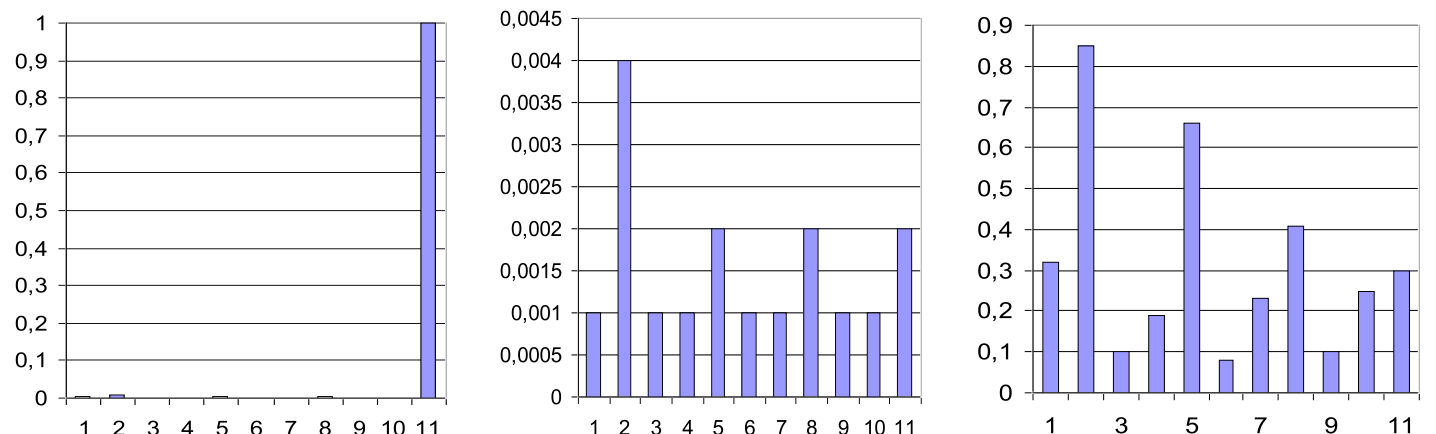

Puc. 3. Содержание а) $\mathrm{Fe}$, б) $\mathrm{Mn}$, в) $\mathrm{Cr}$, г) $\mathrm{Zn}$, д) $\mathrm{Pb}$, e) $\mathrm{Ni}$ ж) $\mathrm{Cu}$, з) $\mathrm{Be}$,

u) $\mathrm{Hg}$ в снеговой воде озера Байкал и прилегающей территории.

Южная котловина: 1 -среднее, 2 -максимальное, 3 -минимальное содержание; Средняя котловина: 4 -среднее, 5 -макс., 6-мин. содержание; Северная котловина: 7 - среднее,

8 -макс., 9 -мин. содержание; озеро Байкал всего: 10 -среднее содержание; 11 - ПДК, ОДК

Результаты химического анализа снега Южной котловины оз. Байкал и прилегающей территории выявили аномалии, приуроченные к долине реки Ангары и населенным пунктам (н.п.) Листвянка, Слюдянка, Култук, Байкальск с повышенными концентрациями для следующих химических элементов и веществ: $\mathrm{NH}_{4}, \mathrm{NO}_{3}, \mathrm{PO}_{4}, \mathrm{NO}_{2}$, $\mathrm{SO}_{4}, \mathrm{~F}, \mathrm{Na}, \mathrm{K}, \mathrm{Cl}, \mathrm{Si}, \mathrm{Ba}, \mathrm{Mn}, \mathrm{Zn}, \mathrm{Fe}, \mathrm{V}, \mathrm{Al}$, $\mathrm{Be}, \mathrm{Sr}, \mathrm{Ti}, \mathrm{Mo}, \mathrm{Pb}, \mathrm{Ni}, \mathrm{Cu}, \mathrm{Hg}$ и нефтепродукты, превышающие фоновые содержания в $30,20,18,13,9,8,8,4,2,20,12,7,7,7,6$, $5,4,4,4,4,3,3,3,3$ и 4 раз соответственно (рис. 2, 3, табл. 1). Фоновые концентрации 
большинства химических элементов в снеге низкие. Содержания аммония, свинца, бериллия, ртути и нефтепродуктов в снеговой воде превышают ПДК в 24, 4, 6, 2, 3 раза соответственно. Их максимальные концентрации зафиксированы на побережье озера.
Mo, Zn, Sr, Ti, Hg Al, Ni, Ba, V, Fе и нефтепродукты, превышающие фоновые значения в $35,20,9,7,4,4,2,13,10,10,7,5$, $5,5,5,4,4,3,2,2,2$ и 4 раз соответственно. Содержания аммония, ртути и нефтепродуктов в снеговом покрове превышают

Таблица 1

Содержание нефтепродуктов, минерализация, рН в воде снега озера Байкал и прилегающей территории

\begin{tabular}{|c|c|c|c|c|c|}
\hline Регион & Содержание & $\mathrm{pH}$ & $\begin{array}{c}\text { Взвещенное } \\
\text { вещество } \\
\text { мг/дм }{ }^{3} \\
\end{array}$ & $\begin{array}{c}\text { Минерализация } \\
\text { мг/дм }\end{array}$ & $\begin{array}{c}\text { Нефтепродукты, } \\
\text { мг/дм }\end{array}$ \\
\hline \multirow[t]{3}{*}{ Южная котловина Байкала } & среднее & 6,44 & 0,070 & 10,8 & 0,050 \\
\hline & $\max$ & 7,14 & 0,559 & 20,1 & 0,202 \\
\hline & $\min$ & 6,06 & 0,001 & 5,84 & 0,008 \\
\hline \multirow[t]{3}{*}{ Средняя котловина Байкала } & среднее & 6,42 & 0,130 & 10,9 & 0,040 \\
\hline & $\max$ & 7,39 & 0,690 & 28,3 & 0,140 \\
\hline & $\min$ & 6,00 & 0,003 & 5,47 & 0,007 \\
\hline \multirow[t]{3}{*}{ Северная котловина Байкала } & среднее & 6,44 & 0,070 & 11,8 & 0,050 \\
\hline & $\max$ & 7,03 & 0,192 & 27,2 & 0,117 \\
\hline & $\min$ & 5,88 & 0,001 & 5,95 & 0,010 \\
\hline Озеро Байкал, всего & среднее & 6,43 & 0,09 & 11,1 & 0,050 \\
\hline \multicolumn{3}{|l|}{ ПДК, ОДК, ГОСТ 2874-82 } & - & - & 0,050 \\
\hline
\end{tabular}

П р и м еч а н и е. ПДК - Предельно допустимая концентрация; ОДК - Ориентировочно допустимая концентрация; ГОСТ - государственный стандарт; взвешенное вещество - твердый остаток на фильтре (пыль); минерализация - сухой остаток (сумма солей).

Согласно проведенным работам в Средней котловине оз. Байкал выявлены аномальные концентрации химических веществ в снежном покрове в Приольхонье, в устье рек Баргузин и Серенги. Обнаружены локальные аномалии в прибрежной зоне Приольхонья, где наблюдается повышенное содержание химических элементов в снеге, что может быть связано с антропогенной нагрузкой вблизи населенных пунктов и турбаз, а также с терригенной пылью пород и почв. Наблюдаются процессы переноса частиц почв и пород на акваторию озера с бесснежных остепненных участков Приольхонья как последствие сильных ветров. Загрязнение снега акватории озера имеет природный и локальный характер. Выявлены высокие содержания токсичных элементов в устье р. Селенга и Баргузин, что может быть следствием переноса техногенных выбросов по долинам рек от ТЭЦ, котельных, строительных и лесоперерабатывающих предприятий н.п. Кабанск, Селенгинск, Усть-Баргузинск и Баргузин.

Повышенные концентрации в снеге Средней котловины оз. Байкал имеют следующие химические элементы и вещества: $\mathrm{NH}_{4}, \mathrm{PO}_{4}, \mathrm{NO}_{3}, \mathrm{~K}, \mathrm{Na}, \mathrm{SO}_{4}, \mathrm{~F}, \mathrm{Cr}, \mathrm{Si}, \mathrm{Pb}, \mathrm{Mn}$, санитарно-гигиенические нормы в 7, 3 и 3 раза. Максимальные значения химических элементов приурочены к побережью озера и имеют локальное распространение.

Анализ проведенных работ в Северной котловине оз. Байкал выявил контрастные аномальные содержания $\mathrm{SO}_{4}, \mathrm{PO}_{4}, \mathrm{NH}_{4}$, $\mathrm{NO}_{3}, \mathrm{Na}, \mathrm{K}, \mathrm{Si}, \mathrm{Ni}, \mathrm{Sr}, \mathrm{Mn}, \mathrm{Cr}, \mathrm{Fe}, \mathrm{Al}, \mathrm{Pb}, \mathrm{Mo}$, $\mathrm{Ba}, \mathrm{Cu}, \mathrm{V}$ и нефтепродуктов, превышающие фоновые значения в $55,12,9,6,6,4$, $14,8,6,5,5,5,4,4,3,3,3,3$ и 2 раза около п.г.т. Нижнеангарска и г. Северобайкальска. Концентрации аммония, свинца и нефтепродуктов в снеге превышают ПДК и ОДК в 2, 7 и 2 раза соответственно. Основные источники загрязнения атмосферы - предприятия строительных материалов, котельные и автотранспорт. Загрязнение побережья имеет локальное распространение.

Согласно проведенным химическим анализам вод оз. Байкал и почв побережья установлено, что современный химический состав воды оз. Байкал с точки зрения ее питьевых качеств отвечает требованиям санитарных норм $[3,7]$ вследствие аккумуляции загрязняющих веществ в почвах и аллювиальных отложениях, а также разбавления огромным количеством воды озера. Однако 
в прибрежных водах (в нескольких метрах от береговой линии) локально обнаружены высокие содержания свинца, фосфатов, аммония и нефтепродуктов, превышающие санитарно-гигиенические нормы вблизи о3. Котокель, н.п. Северобайкальск, Нижнеангарск, Сарма, Черноруд, Танхой, Байкальск, Бугульдейка, Усть-Баргузин, Горячинск, Монахово, Посольское, Дубинино (табл. 2).

Концентрации свинца в прибрежных водах о3. Байкал вблизи п. Черноруд достигают 0,009 мг/дм ${ }^{3}$, п. Бугульдейка 0,06 мг/дм ${ }^{3}$, п. Танхой - 0,010 мг/дм³ , г. УстьБаргузин - 0,020 мг/дм ${ }^{3}$, с. Горячинск 0,020 мг/дм ${ }^{3}$, г. Нижнеангарск - 0,023 мг/дм ${ }^{3}$ (ПДК - 0,001 мг/дм³), что является сочетанием влияния двух факторов - естественное природное повышенное содержание элемента в почвах и почвообразующих породах $[8,9]$, а также поступление вследствие сжигания углей и моторного топлива в береговой зоне и со сточными водами.

Содержание никеля в прибрежных водах около с. Горячинск и п.г.т. Усть-Баргузин превышает ПДК в 3 раза. Сравнение содержания данного элемента с фоновыми природными концентрациями в почвах, грунтах и поверхностных водах свидетельствует об антропогенном генезисе превышений ПДК. Повышенное содержание никеля, относящегося к канцерогенным элементам, имеет техногенное происхождение и связано с промышленными (котельные) и бытовыми (сжигание угля) выбросами.

Максимальное содержание $\mathrm{PO}_{4}$ в прибрежных водах озера около оз. Котокель составляет 0,014 мг/дм³ , п. Сарма - 0,01 мг/дм³ п. Еланцы - 0,04 мг/дм ${ }^{3}$, п. Монахово $0,009 \mathrm{мг} /$ дм $^{3}$, с. Горячинск - 0,06 мг/дм³, с. Посольское - 0,05 мг/дм ${ }^{3}$, п. Бабушкин 0,01 мг/дм³, г. Байкальск - 0,02 мг/дм³ , г. Слюдянка - 0,02 мг/дм ${ }^{3}$ (ПДК - 0,001 мг/дм $\left.{ }^{3}\right)$. Большое количество фосфатов поступает в воду с бытовыми стоками и моющими средствами, что приводит к эвтрофированию водных объектов, в частности пример экологической катастрофы 2008-2011 гг. на оз. Котокель. Развитие возбудителей Гаффской болезни в водах озера по предположению ученых связано с интенсивным развитием хозяйственно-рекреационной деятельности на берегах водоема при недостаточной очистке сточных вод [10].

Максимальные концентрации $\mathrm{NH}_{4}$ в воде устьевых участков рек Вехняя Ангара, Кичера, Сухая, побережья озера напротив населенных пунктов Танхой, Байкальск, Еланцы, Черноруд, Бугульдейка имеют следующие значения - 1,$04 ; 0,55 ; 0,40 ; 0,44 ; 0,48 ; 0,55$; 0,60; 0,64 мг/дм ${ }^{3}$ соответственно (ПДК $0,4 \mathrm{мг} /$ дм $\left.^{3}\right)$. Поступление аммония в озеро обусловлено сбросами канализационных вод и диффузными фильтрациями из индивидуальных септиков. Выявлено высокое содержание меди и цинка в береговых водах, превышающее фоновые концентрации около Ольхонских ворот, н.п. Кубурлик, Горячинск, Выдрино, Большие Коты, Бабушкин, Танхой, Листвянка, Большое Голоустное, УстьБаргузин, Истомино, составляющее более 0,01 мг/дм³ ${ }^{3}$ Концентрации нефтепродуктов в прибрежных водах вблизи н.П. Большое Голоустное, Слюдянка, Максимовщина, Нижнеангарск составляют от 0,06 до 0,34 мг/дм ${ }^{3}$ (ПДК - 0,05 мг/дм³). Источником загрязнения являются предприятия промышленности, энергетики и автотранспорт.

В почвах побережья оз. Байкал обнаружено локальное высокое содержание $\mathrm{Mn}, \mathrm{Pb}$, $\mathrm{Ni}, \mathrm{Co}, \mathrm{Cr}, \mathrm{Zn}, \mathrm{Cu}$ (более 1500, 35, 45, 20, 100, 100, 130 мг/кг соответственно), превышающее ПДК и ОДК побережья оз. Оренгутай, Котокель, Духовое, Чивыркуйского залива, вблизи н.П. Листвянка, Байкальск, Бабушкин, Большое Голоустное, Сарма, Кабанск, Турка, Танхой, Усть-Баргузин, Северобайкальск и Нижнеангарск [2]. Максимальные концентрации химических элементов в почвах по отношению к фону также имеют: $\mathrm{Ba}, \mathrm{Sr}, \mathrm{V}$ и нефтепродукты (1708, 507, 142 и 258 мг/кг), но не превышают санитарно-гигиенические нормативы. Высокое содержание органического вещества, слабощелочная и щелочная реакция среды способствуют накоплению ТМ в почвах береговой зоны, т.е. являются депонирующей средой - «геохимическим барьером» для поступления загрязняющих веществ в оз. Байкал. Однако следует иметь в виду, что почвы, сформированные на карбонатных породах, часто имеют природное высокое фоновое содержание макро- и микроэлементов, например, в Приольхонье.

В водах рек Селенга, Баргузин, Утулик, Турка, Кичера, Верхняя Ангара, Тыя, Мысовка, Переемная, Сухая, Мантуриха, Сарма, Анга обнаружены высокие концентрации F, $\mathrm{Fe}, \mathrm{Pb}, \mathrm{Zn}, \mathrm{Cu}, \mathrm{PO}_{4}, \mathrm{NH}_{4}$. Содержание свинца, фосфатов, аммония, фторидов и нефтепродуктов в воде рек превышают ПДК и ОДК (табл. 3, 4). В водах рек Малая Черемшанка, Большая Черемшанка, Сеннушка, Крестовка, Банная, Ангасолка, Холл, Култучная, Куркавочная, Осиновка, Шаманка, Максимиха, Бабха, Галутай, Харлакта, Голоустная, Паньковка, Энхалух, Большая речка, Хаара-Мурин, Кика, Похабиха, Хаим загрязнения не обнаружено. 
Таблица 2

Содержание химических элементов и веществ в воде озера Байкал

\begin{tabular}{|c|c|c|c|c|c|c|c|c|c|c|c|}
\hline \multirow[t]{2}{*}{$\begin{array}{c}\text { Компо- } \\
\text { нент }\end{array}$} & \multicolumn{3}{|c|}{$\begin{array}{c}\text { Южная котловина } \\
\text { оз. Байкал }\end{array}$} & \multicolumn{3}{|c|}{$\begin{array}{c}\text { Средняя котловина } \\
\text { оз. Байкал }\end{array}$} & \multicolumn{3}{|c|}{$\begin{array}{c}\text { Северная котловина } \\
\text { оз. Байкал } \\
\end{array}$} & \multirow[t]{2}{*}{$\begin{array}{r}\text { Приб. } \\
\text { воды }\end{array}$} & \multirow[t]{2}{*}{ ПДК, ОДК } \\
\hline & $\max$ & $\min$ & сред. & $\max$ & $\min$ & сред. & $\max$ & $\min$ & сред. & & \\
\hline $\mathrm{pH}$ & 7,80 & 6,97 & 7,35 & 7,81 & 6,78 & 7,33 & 7,90 & 6,66 & 7,47 & 8,37 & - \\
\hline $\mathrm{F}$ & 0,650 & 0,060 & 0,270 & 0,210 & 0,004 & 0,122 & 0,652 & 0,091 & 0,443 & 1,060 & $0,7-1,5$ \\
\hline $\mathrm{HCO}_{3}$ & 93,33 & 32,12 & 57,39 & 81,74 & 10,01 & 40,13 & 79,30 & 29,70 & 50,27 & 104,07 & - \\
\hline $\mathrm{Cl}$ & 2,02 & 0,01 & 0,24 & 0,06 & 0,01 & 0,03 & 0,04 & 0,01 & 0,02 & 3,57 & 350 \\
\hline $\mathrm{SO}_{4}$ & 8,80 & 4,95 & 6,07 & 24,75 & 2,18 & 7,37 & 22,00 & 4,21 & 6,89 & 25,08 & 500 \\
\hline $\mathrm{NO}_{2}$ & 0,05 & 0,01 & 0,03 & 0,40 & 0,01 & 0,06 & 0,04 & 0,01 & 0,02 & 1,260 & - \\
\hline $\mathrm{NO}_{3}$ & 0,02 & 0,01 & 0,01 & 0,01 & 0,01 & 0,01 & 0,02 & 0,01 & 0,01 & 55,00 & 130 \\
\hline $\mathrm{PO}_{4}$ & 0,001 & 0,001 & 0,001 & 0,001 & 0,001 & 0,001 & 0,001 & 0,001 & 0,001 & 0,061 & 0,001 \\
\hline $\mathrm{Ca}$ & 30,52 & 10,21 & 17,34 & 18,63 & 10,01 & 15,13 & 28,05 & 10,11 & 14,12 & 41,10 & 180 \\
\hline $\mathrm{Mg}$ & 7,48 & 2,01 & 3,88 & 2,92 & 2,01 & 2,78 & 6,23 & 2,01 & 3,16 & 8,78 & 50 \\
\hline $\mathrm{K}$ & 1,99 & 1,12 & 1,29 & 1,98 & 1,04 & 1,43 & 1,85 & 1,19 & 1,32 & 2,18 & $40-50$ \\
\hline $\mathrm{Na}$ & 4,78 & 2,24 & 2,65 & 3,98 & 2,01 & 2,75 & 2,29 & 2,05 & 2,56 & 8,51 & $120-200$ \\
\hline $\mathrm{NH}_{4}$ & 0,100 & 0,010 & 0,040 & 0,030 & 0,010 & 0,015 & 0,030 & 0,010 & 0,013 & 0,640 & 0,4 \\
\hline Mo & 0,022 & 0,001 & 0,003 & 0,016 & 0,001 & 0,004 & 0,020 & 0,001 & 0,003 & 0,102 & 0,25 \\
\hline $\mathrm{Mn}$ & 0,080 & $0^{*}$ & 0,012 & 0,013 & 0* & 0,002 & 0,008 & $0^{*}$ & 0,003 & 0,080 & 0,1 \\
\hline $\mathrm{Ba}$ & 0,070 & 0,007 & 0,019 & 0,017 & 0,009 & 0,013 & 0,036 & 0,008 & 0,015 & 0,070 & 0,7 \\
\hline $\mathrm{Al}$ & 0,049 & 0,017 & 0,026 & 0,033 & 0,010 & 0,017 & 0,051 & 0,020 & 0,026 & 0,120 & 0,5 \\
\hline $\mathrm{Pb}$ & 0,009 & 0* & 0,001 & 0,010 & $0 *$ & 0,001 & 0,010 & 0* & 0,001 & 0,023 & $0,01-0,001$ \\
\hline $\mathrm{Ni}$ & 0,001 & $0 *$ & $0^{*}$ & 0,001 & $0^{*}$ & 0* & 0,001 & $0 *$ & $0^{*}$ & 0,010 & 0,02 \\
\hline $\mathrm{Cu}$ & 0,009 & 0,001 & 0,004 & 0,009 & 0,001 & 0,003 & 0,009 & 0,001 & 0,004 & 0,026 & 1,0 \\
\hline $\mathrm{Be}$ & 0,001 & $0 *$ & $0^{*}$ & 0,001 & $0 *$ & 0,001 & \begin{tabular}{|l|}
0,001 \\
\end{tabular} & $0^{*}$ & 0,001 & 0,002 & 0,002 \\
\hline $\mathrm{V}$ & 0,001 & 0,001 & 0,001 & 0,001 & 0,001 & 0,001 & 0,001 & 0,001 & 0,001 & 0,007 & - \\
\hline $\mathrm{Cr}$ & 0,002 & $0^{*}$ & 0,001 & 0,001 & $0^{*}$ & 0,001 & 0,001 & 0* & $0^{*}$ & 0,010 & 0,05 \\
\hline $\mathrm{Fe}$ & 0,022 & 0,001 & 0,006 & 0,040 & 0,001 & 0,006 & 0,160 & 0,002 & 0,028 & 0,165 & 0,3 \\
\hline $\mathrm{Si}$ & 7,144 & 0,001 & 1,122 & 1,465 & 0,001 & 0,219 & 4,471 & 1,392 & 2,325 & 6,510 & 10 \\
\hline $\mathrm{Zn}$ & 0,010 & $0 *$ & 0,003 & 0,002 & $0 *$ & 0,001 & 0,001 & $0^{*}$ & $0^{*}$ & 0,090 & $5-1$ \\
\hline $\mathrm{Sr}$ & 0,620 & 0,001 & 0,107 & 0,117 & 0,010 & 0,044 & 0,262 & 0,046 & 0,093 & 0,620 & 7 \\
\hline $\mathrm{Ti}$ & 0,001 & 0,001 & 0,001 & 0,001 & 0,001 & 0,001 & 0,001 & 0,001 & 0,001 & 0,002 & - \\
\hline $\mathrm{Co}$ & 0,002 & 0* & 0,001 & 0,002 & 0* & 0,001 & 0,002 & $0^{*}$ & 0,001 & 0,002 & 0,1 \\
\hline $\mathrm{Cd}$ & 0,001 & $0^{*}$ & 0,001 & 0,001 & $0^{*}$ & $0^{*}$ & 0,001 & $0^{*}$ & 0,001 & 0,003 & $0,001-0,005$ \\
\hline $\mathrm{Hg}$ & 0,01 & 0,01 & 0,01 & 0,01 & 0,01 & 0,01 & 0,01 & 0,01 & 0,01 & 0,12 & $0,3-0,5$ \\
\hline Petrol. & 0,049 & 0,011 & 0,018 & 0,045 & 0,010 & 0,018 & 0,049 & 0,005 & 0,015 & 0,338 & 0,05 \\
\hline Susp. & 0,0086 & 0,0001 & 0,0030 & 0,0262 & 0,0003 & 0,0108 & 0,0290 & 0,0010 & 0,0060 & 0,0110 & - \\
\hline$\sum^{* * *}$ & 135,53 & 63,20 & 89,25 & 113,27 & 37,43 & 69,38 & 120,83 & 53,35 & 82,00 & 160,32 & - \\
\hline
\end{tabular}

П р и м еч а н и е. $0 *$ - менее 0,001 ; ПДК, ОДК** - предельно допустимые и ориентировочные концентрации; $\sum^{* * *}$ - минерализация; сред. - среднее содержание; Приб. - прибрежные воды оз. Байкал; Petrol. - нефтепродукты; Susp. - взвешенное вещество (твердый остаток на фильтре, пыль). $\mathrm{F}, \mathrm{HCO}_{3}, \mathrm{Cl}, \mathrm{SO}_{4}, \mathrm{NO}_{2}, \mathrm{NO}_{3}, \mathrm{PO}_{4}, \mathrm{Ca}, \mathrm{Mg}, \mathrm{K}, \mathrm{Na}, \mathrm{NH}_{4}, \mathrm{Mo}, \mathrm{Mn}, \mathrm{Ba}, \mathrm{Al}, \mathrm{Pb}, \mathrm{Ni}, \mathrm{Cu}, \mathrm{Be}, \mathrm{V}, \mathrm{Cr}, \mathrm{Fe}, \mathrm{Si}, \mathrm{Zn}$, $\mathrm{Sr}, \mathrm{Ti}, \mathrm{Co}, \mathrm{Cd}$, нефтепродукты, минерализация (мг/дм³ $)$; $\mathrm{Hg}\left(\right.$ мкг/дм³); Взвешенные вещества $\left(г /\right.$ дм $\left.^{3}\right)$. 
Содержание химических элементов и веществ в воде рек Селенга, Баргузин, Верхняя Ангара и Тыя

\begin{tabular}{|c|c|c|c|c|c|c|c|c|c|c|c|c|}
\hline \multirow{2}{*}{$\begin{array}{c}\text { Компо- } \\
\text { нент }\end{array}$} & \multicolumn{3}{|c|}{ Селенга } & \multicolumn{3}{|c|}{ Баргузин } & \multicolumn{3}{|c|}{ Верхняя Ангара } & \multicolumn{3}{|c|}{ Тыя } \\
\hline & $\max$ & nin & ед. & $\operatorname{lax}$ & $n$ & . & ax & in & ред. & ax & $\min$ & ред. \\
\hline $\mathrm{pH}$ & 9,72 & & & 5 & 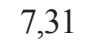 & & & 0 & & 8,01 & 7,46 &, 77 \\
\hline $\mathrm{F}$ & 140 & 559 & 162 & 223 & 085 & 164 & 234 & 105 & 5 & 18 & 0,041 & 105 \\
\hline $\mathrm{HCO}_{3}$ & 5,35 & 18,12 & 1,84 &, 06 & 5,58 & 5,27 & 8,01 & 40,36 & 48,75 & 76,05 & 37,08 & 57,29 \\
\hline $\mathrm{Cl}$ & 93 & 1,78 & 2,49 & 18,50 & 1,60 & 4,12 & 2,50 & 0,19 & 0,20 & 2,32 & 1,96 & 11 \\
\hline $\mathrm{SO}_{4}$ & 0 & 1,00 & (ס) & 0 & 1 & 2 & 9,37 & 1,00 & 0 & 0 & 0,10 & 70 \\
\hline $\mathrm{NO}_{2}$ & 101 & 1 & 021 & 200 & 0,000 & 0,034 & 0,041 & ,0 & 6 & 02 &, 003 & 0,010 \\
\hline $\mathrm{NO}_{3}$ & 00 & $0 \Omega 1$ & 220 & 60 & $\overrightarrow{01}$ & 155 & 60 & $\overline{01}$ & 0,19 & 3,60 & 0,0 & 1,16 \\
\hline $\mathrm{PO}_{4}$ & 061 & 001 & 017 & 077 & $00_{2}$ & 01 & 100 & 000 & 005 & 10 & 000 & 0,006 \\
\hline $\mathrm{Ca}$ & 7,40 & 4,46 & 28,92 & 38,85 & 16,80 & 28,95 & 15,88 & 10,06 & 14,32 & 21,79 & 16,01 & 18,13 \\
\hline $\mathrm{Mg}$ & & & 5,96 &, 55 & 3,39 & 4,33 & & & & & & 4,46 \\
\hline $\mathrm{K}$ & & ד & 1,70 & 2,90 & 0,0 & דוגו ו & $1,0 J$ & 0,20 & 0,13 & & 0,10 & 0,74 \\
\hline $\mathrm{Na}$ & 21,02 & 0,17 & הנ, & ונכ,11 & 1,0 & (T, & (50, & 1,0 & 2,07 & (2, & 0,01 & 2,11 \\
\hline $\mathrm{NH}_{4}$ & 0,150 & 0,001 & 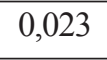 & 0,250 & 0,012 & 0,059 & 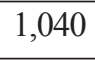 & , & 0 & 0,225 & 1 & 079 \\
\hline Mo & (1) & 01 & 0,000 & 0,011 & , & 0,000 & 0,021 & 0,001 & 0,003 &, 00 & 0,001 & 0,011 \\
\hline $\mathrm{Mn}$ & . & (1) & , & 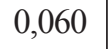 & , & (2), & 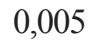 & 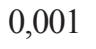 & 03 & 2020 & 0,001 & 0,008 \\
\hline $\mathrm{Ba}$ & 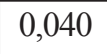 & . & 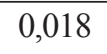 & 24 & 0,010 & 0,019 & 0 & & & 0,020 & & 11 \\
\hline $\mathrm{Al}$ & . & 001 & 0,000 & , & 0,001 & 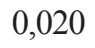 & 0,030 & & & & & 0,065 \\
\hline $\mathrm{Pb}$ & 020 & 001 & 0,003 & 020 & 001 & $0,0($ & 0,003 & 0,0 & 0,002 & 0,003 & 0,001 & 0,002 \\
\hline $\mathrm{Ni}$ & 050 & 001 & 0,004 & 001 & 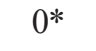 & 0,001 & 0,002 & 0 & 0,001 & 0,002 & & 0,001 \\
\hline $\mathrm{Cu}$ & 0,020 & 001 & 0,006 & 0,004 & 0,001 & 0,001 & 0,008 & 0,001 & 0,002 & 0,005 & 0,001 & 0,003 \\
\hline $\mathrm{Be}$ &, 002 & 001 & 0,001 & 0,001 & $0^{*}$ & 0,001 & 0,002 & $0 *$ & 0,001 & 0,002 & $0^{*}$ & 0,001 \\
\hline V & 0,005 & 0,001 & 0,001 & 0,003 & 001 & 0,001 & 0,008 & 0,001 & 0,004 &, 010 & 0,001 & 0,004 \\
\hline $\mathrm{Cr}$ & 0,010 & 0,001 & 0,001 & (2) & 年 & 0,001 & & 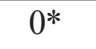 & & & & 0,002 \\
\hline $\mathrm{Fe}$ & 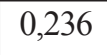 & 0,001 & 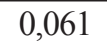 & & $0^{*}$ & 0,043 & & & & & 0 , & 16 \\
\hline $\mathrm{Si}$ & 490 & 221 & 3,513 & 7,640 & 0,200 & 2,6 & 0 & 0 , & 020 & 955 & 0,330 & 2,540 \\
\hline $\mathrm{Zn}$ & 20 & 01 & 0,028 & 2 & 001 & 0,001 & 005 & 0,001 & 2 & 2 & & 0,014 \\
\hline $\mathrm{Sr}$ & 70 & 20 & 0,145 & 0 & 0,0गכ & 0, & 0,1 & 0,002 & 0,063 & 0 & 0,042 & 0,092 \\
\hline $\mathrm{Ti}$ & 0,020 & 0,001 & 0,007 & 0,005 & 0,001 & 0,002 & 0,006 & 0,001 & 0,003 & 0,008 & 0,001 & 0,004 \\
\hline Co & 0,010 & 0,001 & 0,003 & 0,002 & 0 & 0,001 & 0,001 & 0,001 & 0,001 & & 0,001 & 0,002 \\
\hline $\mathrm{Cd}$ & 0,001 & 0,001 & 0,001 & 0,002 & $0^{*}$ & 0,001 & 0,001 & $0^{*}$ & 0,001 & 0,001 & $0^{*}$ & 0,001 \\
\hline 15 & & 政 & 01 & 0,01 & 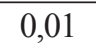 & 0 & 0,02 & 0,01 & 0 & 0,02 & $\overline{a r}$ & 1 \\
\hline Petrol. & 29 & 0,001 & 0,016 & 0,082 & 0,002 & 0,004 & $\mathbf{0 , 0 8 0}$ & 0,001 & 0,018 & 0,068 & 0,003 & 0,007 \\
\hline Susp. & 0,160 & 0,025 & 0,096 & 0,169 & 0,042 & 0,111 & 0,053 & 0,043 & 0,048 & 0,103 & 0,041 & 0,056 \\
\hline$\sum^{* * *}$ & 14,95 & 28,05 & 39,58 & 20,23 & 96,51 & 11,56 & 84,28 & 62,11 & 75,43 & 108,92 & 66,45 & 86,29 \\
\hline
\end{tabular}

Пр и м еч ан и е . 0* и другие см. в табл. 2. Расход воды рек: Селенга - 775-2140, Баргузин 86-175, Верхняя Ангара - 67-128, Тыя - 92-112 л/с. 
Содержание химических элементов и веществ в воде

Таблица 4 рек Кичера, Турка, Утулик, Сарма и Анга

\begin{tabular}{|c|c|c|c|c|c|c|c|c|c|c|c|c|}
\hline \multirow{2}{*}{$\begin{array}{c}\text { Компо- } \\
\text { нент }\end{array}$} & \multicolumn{3}{|c|}{ Кичера } & \multicolumn{3}{|c|}{ Турка } & \multicolumn{3}{|c|}{ Утулик } & \multicolumn{3}{|c|}{ Сарма, Анга } \\
\hline & $\max$ & $\min$ & оед. & hax & $\min$ & ред. & $\operatorname{nax}$ & $\min$ & ред. & $\max$ & $\min$ & сред. \\
\hline $\mathrm{pH}$ & 7,99 & 7,96 & 7,97 & 8,30 & 7,10 & 7,83 & 7,71 & 7,00 & 7,50 & 8,28 & 7,81 & 7,98 \\
\hline $\mathrm{F}$ & 181 & 169 & 0,175 &, 195 & 0,078 & 0,141 & 0,158 & 0,060 & 0,109 & 0,191 & 0,070 & 0,112 \\
\hline $\mathrm{HCO}_{3}$ & 11 &, 09 & 32,60 &, 12 & 21,02 & 30,71 & 5,32 & 55,01 & 5,17 & 2,02 & 36,50 & 0,32 \\
\hline $\mathrm{Cl}$ & 0,41 & 0,20 & 0,20 & 0,31 & 0,18 & 0,24 & 2,50 & 0,18 & 0,21 & 2,50 & 0,20 & 0,67 \\
\hline $\mathrm{SO}_{4}$ & 4,10 & 0,70 & 1,10 & 8,50 & 0,10 & 1,70 & 2,00 & U & 4,01 & 0,10 & 0,10 & 5,23 \\
\hline $\mathrm{NO}_{2}$ & 0,022 & 07 & 0,022 & 02 & $0 c$ & 0 & 650 & 00 & ,029 &, 050 &, 004 & 0,020 \\
\hline $\mathrm{NO}_{3}$ & 01 & 001 & 001 &, 50 & 001 & 011 & 1,15 & 0,85 & 1,00 & 1,60 & 0,01 & 2,67 \\
\hline $\mathrm{PO}_{4}$ & 023 & 0,005 & 0,014 & 0,021 & 0,001 & 0,004 & 0,002 & 0,001 & 0,002 & 0,060 & 0,002 & 0,028 \\
\hline $\mathrm{Ca}$ & 15,99 & 10,41 & 13,20 & 15,10 & 9,18 & 12,41 & 31,78 & 13,60 & 17,69 & 37,63 & 16,80 & 28,24 \\
\hline $\mathrm{Mg}$ & I & $2,1 J$ & 2,13 & $5, \angle 0$ & 1,10 & 2,43 & 7,69 & 4,95 & 3,82 & כ,כ, & 3,41 & 6,34 \\
\hline $\mathrm{K}$ & 30 & 41 & 0,69 & 5,10 & 0,73 & 1,43 & 5,03 & 0,98 & 2,10 & 1,89 & 0,31 & 0,75 \\
\hline $\mathrm{Na}$ & J & 1,70 & 2,57 & 8,34 & 1,95 & 3,86 & 5,23 & 4,49 & 4,86 & 3,36 & 0,67 & 1,73 \\
\hline $\mathrm{NH}_{4}$ & 550 & 27 & 0,119 & 20 & 0007 & 0,055 & 0,025 & 0,015 & 0 & 6 & 5 & 9 \\
\hline Mo & 005 & 001 & 003 & ,014 & 0,001 & 0,004 & 009 & 0,001 & 5 & 009 &, 001 & 0,005 \\
\hline $\mathrm{Mn}$ & 0 & 0,001 & 0,002 & ( & 0,001 & 0,00 & 0,010 & , & 0,001 & 0,010 &, 001 & 0,007 \\
\hline $\mathrm{Ba}$ & - & 0,010 & U, & 0,013 & & 0,009 & 0,017 & 0,0 & & 0,019 & 0,009 & 0,016 \\
\hline $\mathrm{Al}$ & 021 & 0,018 & 0,020 & 0,038 & 0,00 & 0,013 & 0,057 & 0,001 & 0,030 & 0,057 & 0,001 & 0,030 \\
\hline $\mathrm{Pb}$ & 040 & & 0,002 & 0,013 & 0,001 & 0,003 & 0,011 & 0,001 & 0,002 & 0,011 & 0,001 & 0,002 \\
\hline $\mathrm{Ni}$ & 002 & 0,001 & 0,002 & 0,005 & $\sigma$ & 0,001 & 0,001 & 0,001 & 0,001 & 0,001 & 0,001 & 0,001 \\
\hline $\mathrm{Cu}$ & 000 & 0,002 & 0,004 & 0,005 & 0,0 & 0,002 & 0,001 & 0,001 & 0,001 & 0,001 & 0,001 & 0,001 \\
\hline $\mathrm{Be}$ & 002 & 0 & 0,001 & $\rho \cap 01$ & $0:$ & $0 *$ & $0 *$ & $0 *$ & $0:$ & $0 *$ & $0 *$ & $0 *$ \\
\hline $\mathrm{V}$ & 001 & & ד, ס, & , & 0 & 0,001 & 0,004 & 0,001 & 0,002 & 0,004 & 0,001 & 0,002 \\
\hline $\mathrm{Cr}$ & 0 & 0,001 & 1 & 0 , & 0 & 0 & 0* & $0^{*}$ & $0 *$ & $0 *$ & $0^{*}$ & $0 *$ \\
\hline $\mathrm{Fe}$ & 040 & 0,013 & 0,024 & 0,215 & 0* & 0,068 & 0,080 & $0 *$ & 0,028 & 0,080 & $0 *$ & 0,028 \\
\hline $\mathrm{Si}$ & 150 & 0,790 & 2,016 & 6,984 & 0,015 & 3,472 & 4,610 & 2,537 & 3,769 & 4,610 & 2,536 & 3,769 \\
\hline $\mathrm{Zn}$ & 0,002 & 0,001 & 0,002 & 0,004 & $0^{*}$ & 0,001 & 0,012 & 0,002 & 0,009 & 0,012 & 0,002 & 0,009 \\
\hline $\mathrm{Sr}$ & 0,130 & 0,055 & 0,081 & 0,101 & 0,050 & 0,074 & 0,127 & 0,058 & 0,097 & 0,127 & 0,058 & 0,097 \\
\hline $\mathrm{Ti}$ & 0,005 & 0,001 & 0,003 & 0,010 & 0 & 0,002 & 0,006 & 0,001 & 0,003 & 0,006 & 0,001 & 0,003 \\
\hline Co & 0,004 & 0 & 0,002 & 0,002 & 0,00 & 0,001 & 0,001 & $0 *$ & $0^{*}$ & 0,001 & $0 *$ & $0 *$ \\
\hline $\mathrm{Cd}$ & 0,002 & $0 *$ & 0,001 & 0,001 & 0 & 0,001 & 0,001 & 0 & 0 & 0,001 & 0* & 0* \\
\hline $\mathrm{Hg}$ & 0,01 & 0,01 & 0,01 & 0,02 & 0,01 & 0,01 & 0,01 & 0,01 & 0,01 & 0,01 & 0,01 & 0,01 \\
\hline Petrol. & 0,009 & 0,007 & 0,008 & 0,008 & $0^{*}$ & 0,005 & 0,012 & $0 *$ & 0,006 & 0,016 & 0,003 & 0,009 \\
\hline Susp. & 0,049 & 0,047 & 0,048 & 0,067 & 0,047 & 0,059 & 0,130 & 0,041 & 0,086 & 0,080 & 0,035 & 0,050 \\
\hline$\sum^{* * *}$ & 59,84 & 48,33 & 54,09 & 63,99 & 40,85 & 53,81 & 118,90 & 109,42 & 114,16 & 129,62 & 96,53 & 109,00 \\
\hline
\end{tabular}

П р и м еч ан и е . $0 *$ и другие см. в табл. 2. Расход воды рек: Кичера - 167-186, Турка - 39-151, Утулик - 19-56, Сарма - 990-1146, Анга - 4687-5690 л/с. 
Концентрации фтора в воде реки Селенга и минеральных источников Хакусы достигают более 3 мг/дм³ ${ }^{3}$ Максимальное содержание свинца в воде рек Утулик, Турка, Баргузин, Селенга, Кичера составляет 0,$011 ; 0,013 ; 0,020 ; 0,020 ; 0,40$ мг/дм ${ }^{3}$ соответственно. Высокие концентрации $\mathrm{PO}_{4}$ выявлены в реках Турка, Кичера, Селенга, Баргузин, Верхняя Ангара, Тыя, Мысовка, Переемная, Мантуриха, мин. ист. Хакусы имеющие значения - 0,02, 0,02, 0,06, 0,08, $0,10,0,10,0,11,0,13,0,18,0,23$ мг/дм ${ }^{3}$ соответственно. В теплых озерах на р. Снежной отмечается также повышенное содержание фосфатов - 0,02 мг/дм³.

Максимальные содержания $\mathrm{NH}_{4}$ обнаружены в воде рек Верхняя Ангара, Кичера и Сухая, составляющие 1,04, 0,55 и 0,40 мг/дм ${ }^{3}$. Концентрации нефтепродуктов в воде рек Селенга, Верхняя Ангара, Баргузин, Тыя составляют 0,$13 ; 0,08 ; 0,08$; $0,07 \mathrm{Mг} /$ дм $^{3}$ соответственно. Поступление биогенных элементов, таких как фосфаты и соединения азота, провоцирует эвтрофирование водных объектов, что наблюдается на многих мелководных участках прибрежной зоны оз. Байкал и представляет предмет экологического риска для озера.

Содержание цинка в водах рек Селенга, Кичера, Баргузин, Тыя, Турка, Пеемная, Большая речка, Мантуриха, минеральных источников Хакусы превышает 0,01 мг/дм³. Концентрация железа в реках Селенга, Баргузин, Турка, Максимиха, Сухая превышает фоновые содержания и составляет 0,140,24 мг/дм³. Ландшафты устьевых участков рек, являющиеся геохимическим барьером для токсических веществ, аккумулируют загрязняющие вещества. Происходит самоочищение вод рек благодаря загрязнению других компонентов ландшафтов. Не исключено, что при благоприятных условиях, например при перенасыщении или при подкислении среды, может произойти переход токсичных элементов в водные объекты.

\section{Заключение}

Полученные результаты проведенных исследований говорят о значительном воздействии промышленных производств на окружающую среду оз. Байкал, которое проявляется на региональном и локальном уровнях. Загрязнение атмосферного воздуха и снега акватории оз. Байкал по результатам проведенных работ отмечается вблизи прибрежных населенных пунктов Листвянка, Култук, Слюдянка, Байкальск, УстьБаргузин, Нижнеангарск и Северобайкальск и в устье р. Селенги. Концентрации большинства изученных химических элементов и веществ в снеге фоновой территории Байкальского региона низкие, ниже ПДК в десятки - тысячи раз. Вследствие аккумуляции загрязняющих веществ на геохимических барьерах почв и аллювиальных отложений, а также ее разбавления вода Байкала соответствует санитарным нормам. Однако имеются локальные участки с повышенным содержанием токсичных элементов и веществ в прибрежных водах оз. Байкал и почвах вблизи населенных пунктов побережья. Выявлены высокие содержания загрязняющих веществ в реках, впадающих в озеро. Необходимо информировать местное население и туристов об экологическом состоянии окружающей среды рекреационных и санаторно-курортных зон, ограничить или регламентировать использование вод рек, побережья, минеральных источников с опасно высоким содержанием фтора, свинца, никеля и других токсичных элементов и веществ.

Работы проведены при финансовой поддержке гранта РФФИ № 16-05-00286, ФЦП "Охрана оз. Байкал и сочиально-экономическое развитие БПТ на 2012-2020 г2.», проектов НИР № 0347-2016-0002 и 0347-2016-003.

\section{Список литературы / References}

1. Белозерцева И.А., Воробьева И.Б., Власова Н.В., Янчук М.С., Лопатина Д.Н. Химический состав снега акватории озера Байкал и прилегающей территории // География и природные ресурсы. 2017. № 1. C. 90-99. DOI: 10.21782/ GIPR0206-1619-2017-1(90-99)

Belozertseva I.A., Vorobjeva I.B., Vlasova N.V., Janchuk M.S., Lopatina D.N. Chemical Composition of Snow in the Water Area of Lake Baikal and on the Adjacent Territory // Geography and Natural Resources, 2017, Vol. 38, № 1 P. 68-77 DOI: $10.1134 / \mathrm{S} 1875372817010097$.

2. Белозерцева И.А., Сороковой А.А., Бешенцев А.Н., Пахахинова 3.3., Батхишиг О., Оюунчимэг Т. Деградация и загрязнение почв Экологический атлас бассейна озера Байкал. Карта 1:5000000 Мб. Иркутск: Ин-т географии им. В.Б. Сочавы CO PAH, 2015. C. 96-98. URL: https://elibrary.ru/ download/elibrary 25207934 33392312.pdf (дата обращения: 01.08.2018).

Belozertseva I.A., Sorokovoi A.A., Beshentsev A.H., Pakhakhinova Z.Z., Butkhishig O., Oyunchimeg T. Degradation and Pollution of Soils. Ecological Atlas of the Lake Baikal's basin. Map 1:5000000 Mb. Irkutsk: V.B. Sochava Institute of Geography of the Siberian Branch of the Russian Academy of Sciences, 2015. P. 96-98. URL: https://elibrary.ru/download/ elibrary_25207934_33392312.pdf (date of access: 08.01.2018) (in Russian).

3. Воробьева И.Б., Белозерцева И.А., Власова Н.В., Янчук М.С. 2018 Современное состояние водотоков в устьевых областях восточного побережья озера Байкал // Успехи современного естествознания. 2018. № 1. C. 86-92.

Vorobyeva I.B., Belozertseva I.A., Vlasova N.V., Janchuk M.S. Current State of the Stream Flows in the Estuary Areas of the Eastern Coast of Lake Baikal // Modern problems of science and education. 2018. № 1. P. 86-92 (in Russian).

4. Ветров В.А., Кузнецова А.И. Микроэлементы в природных средах региона озера Байкал. Новосибирск: Наука, 1997. $237 \mathrm{c}$. 
Vetrov V.A. and Kuznetsova A.I. Microelements in the Natural Environments of the Lake Baikal Area. Novosibirsk: Science, 1997. 237 p. (in Russian).

5. Оболкин В.А., Нецветаева О.Г., Голобокова Л.П., Потемкин В.Л., Зимник Е.А., Филлипова У.Г., Ходжер Т.В. Результаты многолетних исследований кислотных выпадений в районе Южного Байкала // География и природные ресурсы. 2013. № 2. C. 66-73.

Obolkin V.A., Netsvetaeva O.G., Golobokova L.G., Potyomkin V.G., Zimkin E.A., Fillipova U.G., Khodzher T.V. Results of long-term investigations on acid deposition in the area of South Baikal. Geography and Natural Resources. 2013. T. 34 № 2. P. 151-157. DOI: 10.1134/S1875372813020078.

6. Ходжер Т.В., Сороковикова Л.М. Оценка поступления растворимых веществ из атмосферы и с речным стоком в озеро Байкал // География и природные ресурсы. 2007 № 3. C. $185-190$.

Khodzher T.V. and Sorokovikova L.M. An assessment of the entry of soluble substances from the atmosphere and with the river runoff into Lake Baikal. Geography and Natural Resources, 2007. № 3. P. 185-191 (in Russian).

7. Грачев М.А. Стратегия охраны озера Байкал и Закон «Об охране озера Байкал». Иркутск: Лимнологический институт CO PAH, 2013. 36 c. URL: http://libbabr.com/ext/20798. pdf (дата обращения: 01.08.2018).

Grachev M.A. Lake Baikal Environmental Protection Strategy and Lake Baikal Conservation Law. Moscow SB RAS
Limnological Institute, 2013. 36 p. URL: http://libbabr.com/ ext/20798.pdf (date of the address: 08.01.2018) (in Russian).

8. Гребенщикова В.И., Лустенберг Э.Е., Китаев Н.А., Ломоносов И.С. Геохимия окружающей среды Прибайкалья (Байкальский геоэкологический полигон). Новосибирск: Гео, 2008. 234 c.

Grebenshikova V.I., Lustenberg E.E., Kitayev N.A. and Lomonosov I.S. Geochemistry of the Baikal Environment (Baikal geoecological test site). Novosibirsk: Geo, 2008. 234 p. (in Russian).

9. Убугунов В.Л., Убугунова В.И. Почвообразующие породы - ключ к пониманию самобытности почвообразования в Западном Забайкалье // Природа Внутренней Азии. 2017. № 4 (5). С. 37-50.

Ubugunov V.L., Ubugunova of V.I. Pochvoobrazuyushchiye of breed - a key to understanding of identity of soil formation in the Western Transbaikalia // Nature of Inner Asia. 2017. № 4 (5). P. 37-50 (in Russian).

10. Сороковикова Е.Г., Белых О.И., Гладких А.С., Могильникова Т.А., Федорова Г.А., Кузьмин А.В., Михеева Т.М. Токсичные цветения цианобактерий в оз. Котокельское (Бурятия) - современное состояние проблемы // Вода: химия и экология. 2014. № 2 (67). С. 29-35.

Sorokovikova E.G., White O.I., Smooth Ampere-second., Mogilnikova T.A., Fedorova G.A., Kuzmin A.V., Mikheyev T.M. Toxic blossomings of cyanobacteria in the Lake Kotokelskoye (Buryatia): the current state of a problem // Water: chemistry and ecology. 2014. № 2 (67). P. 29-35 (in Russian). 